\title{
On Dramatic Narrative in Caryl Churchill's Vinegar Tom
}

\author{
Fengshan $\mathrm{Bi}^{1}$ \\ ${ }^{1}$ Yancheng Teachers University, Jiangsu, China \\ Correspondence: Fengshan Bi, School of Foreign Language, Yancheng Teachers University, Jiangsu, China.
}

Received: October 5, 2018 Accepted: October 30, 2018 Online Published: November 28, 2018

doi:10.5539/ells.v8n4p70 URL: https://doi.org/10.5539/ells.v8n4p70

\begin{abstract}
Caryl Churchill, in Vinegar Tom, discloses the social plight of marginalized and powerless women through her innovative theatrical methods. The episodic scenes, coupled with cross-cast doubling and contemporary songs, contribute to the formation of a plurality of theatrical implication. Churchill's experimentation with dramatic narrative, which ingeniously interweaves with feminist theory and gender politics, represents her attempt to explore the possibilities of a feminist aesthetic. The play challenges the dominant versions of witchcraft history as constructed by patriarchy, and simultaneously, points out the continuing impact of gender constrictions on women in contemporary society. Churchill's commitment to social injustice requires the use of innovative theatrical forms.
\end{abstract}

Keywords: Vinegar Tom, episodic structure, cross-cast doubling, the interspersion of songs

\section{Introduction}

Vinegar Tom, which Churchill wrote in association with the Fringe Theater Monstrous Regiment, is her dramatization of seventeenth-century witch persecutions. It was staged in 1976 at the Humberside Theatre, Hull. Those women in one North Country English community were accused as witches precisely because they were "on the edges of society, old, poor, single, sexually unconventional" (Churchill, 1985, p. 130). By rewriting the historical events, Churchill critiqued patriarchal power, showing how the Christian and academic authorities united with the public to oppress powerless and marginalized women. The persecution of these women is seen as a convenient displacement of other social issues, such as the religious hypocrisy, the complicity of the state and religion, and the clash between medical doctors and herbalists. Hence, it is a play about "witches with no witches in it" and about "poverty, humiliation and prejudice" (Churchill, 1985, p. 130).

\section{Literature Review}

After it was put onto stage, it received different responses from the academic circle. Many commentators explore the gender politics conveyed through the play. Geraldine Cousin reveals that "Vinegar Tom's real concern is with the legacy we carry with us today from the witches and their ancestors. Accusing someone of witchcraft is a way of externalizing all kinds of hidden and unacceptable emotions" (Cousin, 1989, pp. 37-38). Sanjoy Kr. Seal, with Dr. Dipendu Das, points out that "Churchill has highlighted the dynamics of gender politics and patriarchy by focusing on the issue of artificially imposed gendered roles and identities to women within patriarchy" (Seal, 2015, p. 146). In the words of Susan Todd, Churchill explored the mythology of witchcraft "in terms of the economic pressures and the role of women in society" (Itzen, 1980, p. 275). Mohammand Reza Modarres Zadeh, however, says that the play "senses a more human, more universally cajoling exertion at stake that surpasses the male/female binary and spies into human character itself" (Zadeh, 2013, p. 312). Elaine Aston explores the influences of Monstrous Regiment on Churchill's theatrical writing practice, and this collaboration contributes to Churchill's rising as "a woman writer" (Aston, 2001, p. 31).

In the light of feminist narratology, this essay scrutinizes how social issues and women's consciousness shaped by gender-related conditions influence Churchill's story-telling practice. In other words, it will focus on how Churchill presents the story on stage and how, her identity as a female playwright, influences her choices of arranging the plot, role, and language in the play. Susan Lanser argues that "being a woman in a male dominated society may well necessitate the double voice, whether as conscious subterfuge or tragic dispossession of the self" (Lanser, 1997, p. 681). Through the surface text presented by Churchill in Vinegar Tom, the audience participates in the interpretation of the subtext behind it, which the playwright constructs to criticize gender related problems. Hence, the essay is engaged with the examination of the narrative strategies adopted by 
Churchill to problematize concepts such as sex, gender role, and etc, instigating the audience to reflect on gender persecution as treated in Vinegar Tom. The essay concludes that formal innovation is crucial to Churchill's critique of patriarchy in history as well as in contemporary life.

\section{The Episodic Structure}

Vinegar Tom consists of twenty-one naturalistic scenes, which dramatize the story of a village in which economic dis- crepancy combines with random misfortune to produce a witch hunt. These episodes depict different men and women, who are decentered, and internally contradictory subjects constructed in the experience of class, race, gender, age, and etc. Each individual scene functions as an independent episode.

The opening scene is a two-hander, presenting the audience dramatically with a roadside scene of an unidentified man and Alice, a promiscuous village girl, who have apparently had sex. After their sexual intercourse, Alice asks the man to take her away with him. She wants to leave her surroundings and find a more satisfying life, but she is forced to stay in the country, where she is repeatedly abused. The man refuses to take her away and accuses her of being a whore, claiming she does not fit into any of society's categories for respectable women:

\section{Man: What are you then? What name would you put to yourself? \\ You're not a wife or a Widow. You're not a virgin. \\ Tell me a name for what you are (Churchill, 1985, p.137).}

The man took advantage of Alice just to sate his lust. He loathed her in his heart. Furthermore, the scene establishes the sexual inequality between men and women. While men may move freely, Alice, being a woman with a child, is trapped. The episode introduces an important character, Alice, to the audience. However, dramaturgically, it is separated from the other scenes. The audience will not see the man character again. Moreover, at its close, the scene establishes that this will be the case:

Alice: I'll not call you devil, come back, what's yourname?

Man: You won't need to know it. You won't be seeing me again (Churchill, 1985, p.138).

The closing lines of the scene bring it to an abrupt end. The two-hander scene makes it clear that there will be no further development of this special relationship although the intercourse between them will be mentioned in conversation in later scenes. The thematic concern which the scene aims to elaborate- the disparity in terms of the freedom of the two characters, resulting from their different genders-is emphasized by the final separation of the characters. The man leaves and Alice must remain where she is, though she is eager to leave. Hence, the opening scene directly focuses on the insults and tortures imposed upon poor young women.

The second scene begins with the dialogue between a couple: Jack and Margery, which presents the hierarchical structure of the country estate on which most of the characters live. Margery, as a woman, shows no sympathy for Alice and Joan's exhausted situation. Obviously, Joan is the poorest householder on the estate and living under the threat of eviction. Later, when Jack and Margery see Betty, the landowner's daughter wandering on their land, their discussion establishes the role of Betty's family in the social hierarchy in which they live. Betty's family holds a superior social position in the area. Meanwhile, Margery and Jack are definitely in the middle of the hierarchy. Thus the complex but rigid social hierarchy in which the characters live is made clear to the audience through this episode.

The first few scenes of the play introduce the social causes of the witch-hunt: sexual inequality, economic disparity, and random misfortune, which will be established as contributing factors to the witch hunt later in the play. These scenes jump between locations, with the play's twenty-one scenes taking place in a total of eleven different places, providing a spatial, as well as narrative separation between the episodic segments of the play. Each scene forms a mini-narrative, which demonstrates a part of the playwright's thesis, complete and independent from the bulk of the play. The episodic arrangement of the events interrupts the spontaneous flow of the plot, pulling the audience out of their empathy. It breaks the illusion of reality, thereby instigating the audience to think more critically, in a detached manner.

At the heart of these mini-narratives are the Brechtian gests. In paragraph sixty-six of "A Short Organum for the Theatre", Brecht explains that critical social gests could provide a scene with a focus (Brecht, 1964, p. 200), which helps to draw the audience's attention on the single dramatic moment. In scene five, Jack, whose social status is higher than poor Alice, brings her two apples as an indication of his willingness to barter goods for sex. The two apples throw light on the finite but substantial nature of Jack's power and the dilemma of Alice, who 
could feed not only herself, but also her child, if she were to satisfy Jack's desire. This Brechtian gest, two apples, as Howe Kritzer describes, is "a simple action that illuminates the power relations structuring a situation - to call attention to the interaction of economic and sexual oppression" (Kritzer, 1991, p. 89).

The episodic scene and the use of the Brechtian social gests, while disturbing the linear development of the play, allow Churchill to demonstrate different aspects of the play's thesis in the moment: women are persecuted and scapegoated in the patriarchal society. Furthermore, episodic structure creates an alienation effect which Churchill intends. As Peter Demetz has written in his collection of critical essays on Brecht, "epic theatre, in which stage technique and Marxism finally correspond, strives to keep man [sic] sober, cool and critical" (Demetz, 1962, p. 4). The epic-style acting serves to awaken the audience from what Brecht regarded as a false emotional empathy with characters and theatrical illusion. Instead, the episodic structure encourages a critical and rational response to the conditions portrayed. It is not surprising, therefore, that Churchill chose to convey her socialist convictions within an episodic form. What is remarkable about Churchill is that she has adapted epic theatre conventions, and her own wit into a style uniquely suited to "her socialist-feminist vantage point" (Randall, 1989, p. 81).

\section{The Cross-Cast Doubling}

In the theatre, the actor is able to take on any identity or character role. Audiences for ancient Greek drama, for the Elizabethan theatre, and for classic Chinese opera, not only accept the playing of female characters by men, but assume the actors ability to take on many roles, both male and female. However, the playing of male characters by women is rare in the history of performance. On rare occasions have women been allowed to speak or appear in public. In Vinegar Tom, Churchill creates a complicated relationship between actor and role to challenge the inevitable oppression and empower the characters to seek change. Actors are required to take on several different roles. Moreover, men are sometimes required to be played by women, and the closing scene is a luminous point of the whole play.

The final scene, also a play-within-a-play, forms a sharp contrast with the rest of the scenes. After Joan and Ellen have been hanged, and while Alice and Susan are waiting for their execution, two master theorists of the witch hunts, who wrote the misogynist classic The Hammer of Witches, Kramer and Sprenger, appear as Edwardian male vaudeville performers. Speaking in turn, they explain why the number of female witches is bigger than that of the males. In their minds, women's susceptibility to witchcraft is caused by their physical, intellectual, and moral inferiority. They expound their biblically derived idea that witches are predominantly female because "All wickedness is but little to the wickedness of a woman". They declare that women are inherently inferior in both mind and body, but the primary fault of women is that they are sexually insatiable. In her "Production Note" for Vinegar Tom, Churchill stipulates that "these male characters be played by two women just hanged as Joan and Ellen, and anachronistically assume the attire and stylized patter of Edwardian music-hall comic" (Churchill, 1985, p. 134). Churchill's requirements for the casting of these roles show once more the power of theatre. Obviously, the sexual identity in the history is not natural but is constructed by prevailing gender codes. To question sexual identity in this way is to challenge the theatrical device which commands unitary representation of the individual. While the female actors playing the role of male characters are moving on stage, the audience would understand the preconceptions about sex and gender prevalent in the history were constructed by men. It also throws light on the complex power relations at work in the process of self-identification, especially for women.

The cross-cast doubling also draws the audiences' attention to women's complicity, represented by Margery and Goody, though unconscious, in their own and other women's oppression. That is, the victims become victimizers. Margery, a tenant farmer, refused Joan's request for a little yeast. When she suffered headaches, became weaker, and her cattle suddenly began dying, she insisted good folks get bewitched (Churchill, 1985, p. 153), and she owed all her misfortune to Joan and Alice. Goody, the assistant of Parker, a professional witch finder, let Joan suffer physical torture in order to bring out her confession. Their collusion helps to maintain patriarchal system in the society.

What's more, the cross-cast doubling helps the audience realize that the underlying misogyny that has become so invisible to the patriarchally dominated vision in many contemporary cultures still exists. Amelia Howe Kritzer points out that "the introduction of another historical period as counterpoint to both the seventeenth century and the present further serves to invalidate a simplistic opposition between past and present in attempting to understand gender oppression" (Kritzer, 1991, p. 91). Through playing Kramer and Sprenger as music hall gentlemen, Churchill satirizes the absurd logic relating witches with women and encourages the audience to realize that the entire recorded history of women has been created in and through patriarchal ideology. 
This scene creates an aesthetic break in the flow of the narrative. Indeed, the link between this scene and the rest of the play is thematic. It makes it clear that the play's dominant focus is an idea rather than a particular time period. In this scene, Churchill pulls the audience back from the dual focus on seventeenth-century material conditions and contemporary consciousness to examine the ideology upon which oppression of women is founded. Kramer and Sprenger provoke the audience to reflect on the thematic message of the play played out in the preceding scene:"Should men be better? Should the world be changed?" They are asking in the play's final moments whether or not the use of "evil women" as scapegoats is truly a thing of the past.

By reducing the interrogation and torture of women witches to a music hall popular entertainment, Churchill presents her audience with a parallel for the imaginary excitement potentially felt by spectators at a public event, be it theatre, or an acrobatic show. Sprenger and Kramer are clearly cheats, women playing men; in trying to "pass" they act against their own interests. Spectators who are drawn into this entertainment, are, in fact, made accomplices. Hence, the music hall motif serves to bring the audience back to the nature of theatrical form itself. It might be "an insidious way in which a representational construction may foster a regressive political position" (Randall, 1989, p. 80).

The cross-cast doubling gives audiences the opportunity to view issues with "the double vision necessary to see both what is and what might be" (Kritzer, 1991, p. 192). This risk-taking makes Churchill's scripts increasingly "difficult" for a reader; but, the dynamics of performance involve the spectator in provocative relationships with the world outside and with the aspirations of the on-stage characters. It creates a rich vocabulary whose implications hide behind the "difficult" surface. This role arrangement is intended to disprove the existence of the witchcraft that the sexist theologians condemn. It reinforces the condemnation of stereotypes, shown as the products of "an ignorant fear of female sexuality" (Innes, 2002, p. 513), through ridiculing genuine excerpts from the fifteenth-century book that promoted the victimization of women, as both superstition and cross-talk patter. In addition, this cross-cast doubling creates a comic effect, which elicits questions of stereotype from the audience, and this questioning might result in the change in society.

\section{The Interspersion of Songs}

Unlike many 1970s contemporaries, Churchill has continued to develop new approaches to theatre, exploring daringly theatrical possibilities by "combining densely poetic text with the visual, aural and physical"(Croft, 2001, p. 42). In Vinegar Tom, she intercuts her schematic episodic scenes with seven contemporary songs, which were performed by the acting company appearing out of character and in contemporary dress.

The songs in Vinegar Tom expose more general states of mind, such as fear of change, the desire to be loved, or a craving for security, offering a way of "representing the marginal and the absent in dominant systems of representation" (Aston, 2001, p. 27). The thesis of many scenes is emphasized by a song which follows it. The song "If You Float" summarizes the nonsense logic of the witch-hunt which is hard to deal with.

You may be a mother, a child or a whore.

If you complain you're a witch

Or you're lame you're awitch

.......

Got big tits you're a witch

Fall to bits you're a witch(Churchill, 1985, p. 170).

Sexual identity is not only unambiguous but vividly polarized in the song: women are victims of male oppression, scapegoats for the failures and impotencies that men cannot acknowledge as their own. The best chance women have, one woman in the play advises another, is to "marry a rich man, because it's part of his honor to have a wife who does nothing" (Churchill, 1985, p. 169). "If You Float" highlights women's situation as a "catch 22": "If you float you're a witch /. . . If you sink, then you're dead anyway" (Churchill, 1985, p. 170) The song critiques patriarchal logic which manipulates sign-systems, arbitrarily inventing and re-inventing the "signs" of women's "evil" doing (Aston, 2001, p. 29). It is an accusation: this is what was done to women. According to the production notes, the songs should take place in the present. The actors/actresses ought to perform them "in modern dress" (Churchill, 1985, p. 133). This arrangement would underline the distancing between the actors and the audience, to prevent the naturalistic psychological empathy between the performer and the audience. The audience will not take what happens on stage for granted. The discrepancy prompts them to reflect on the dramatic moment, and to construct the meaning by themselves. 
The conscious awareness of the audience is vital to the play's meaning. If witch is read as a metaphor for woman, the audience can discover that regardless of a woman's stereotypical representation, whether "a mother, a child or a whore", within patriarchy women are inferior in relation to the men of their class or social group. Churchill points out that the silencing of women is an inescapable outcome of patriarchy: "Deny it you're bad / Admit it you're mad / Say nothing at all / They'll damn you to hell". "Bad" or "mad" is constructed by patriarchal ideology to characterize women's speech. By inserting this song, Churchill suggests that even if women accept their enforced silence and say nothing at all, they still cannot find a way out. Both silence and speech become an excuse for condemnation. Masculine power drives all women to the hell of patriarchy, in which "fingers are pointed" and compliant women are damned to the margins of society. Meantime, those women who don't give in are doomed to be wiped out as witches.

Songs are very effective in creating a psychological distance between the audience and the actors. These songs remind the audience of the continuing impact of gender constraint in the late twentieth century. It is important for the audience to see the singers in contemporary dress in order to emphasize the continuity between present and past. Furthermore, it clarifies that the songs are a commentary by the performers on the events within the play. The songs succeed in shifting attention from the horror of events unfolding on stage to the contemporary persecution of women. The witch-hunts that Churchill describes as being her concern in Vinegar Tom is relevant to the conditions of her own time as well, a point made clear in the penultimate song of the play, "Lament for the Witches," which urges the audience to

Look in the mirror tonight.

Would they have hanged you then?

Ask how they're stopping you now.

Where have the witches gone?

Who are the witches now?

Ask how they're stopping younow.

Here we are (Churchill, 1985, p.176).

The common concerns about legal equality in property ownership, employment, and education, as well as abortion rights, which are shared by the characters on stage and the audience off stage, are brought into the foreground through the first person plural narration "Here we are". The pronoun "we" substantially contributes to the unifying attitude conveyed by the play. At this point, the stage, which sings to the public, promises a more dramatic change in the viewpoints of the audience.

Churchill not only responds to immediate events around her, but also acts as an intellectual precursor, often anticipating currents of thinking and expressing them in dramatic forms either before or contemporaneously with their verbalization in theory. Packer's interrogation of Alice in Vinegar Tom foresees a frightening representation of the 1990s campaign against "lone mothers" and "home alone" children by right-wing politicians. They declare that it is "good Christian doctrine" to stop single women having kids before they establish stable relationships. Elaine Aston suggests that the songs "create the opportunity for the performer to insert her body into the performance text as a si[gh]te of disruption" (Aston, 2001, p. 27). The refrain "here we are" calls attention to the moment of performance in which the actresses identify themselves as contemporary individuals rather than historical characters; the present could be a historical moment, elaborating Churchill's view of the continuity of persecution of women throughout history. The songs relate past persecutions to present-day oppression, ensuring that the modern parallels to contemporary sexism, ageism, and capitalism cannot be ignored. It suggests that such persecution continues to thrive in the present.

The final moment of the play, the song "Evil Women," allows contemporary women to have the final word. The lyrics focus primarily on sex and cultural representations of women:

\section{Evil women}

If you like sex sinful, what you want is us...

If we don't say you're big

Do you start to shrink?

We earn our own money 
And buy our own drink(Churchill, 1985, p.178-9).

Contemporary references to the Equal Pay Act ("we earn our own money") and the point about women buying their own drinks, perhaps hinting at the dispute over the Fleet Street wine bar El Vinos refusal to sell women drinks at the bar, even after the Sex Discrimination Act was passed in 1975, bring the audience back to the present. By ending the play on a moment in the present rather than in the past, Churchill offers a direct challenge to the audience, providing no answers but raising provocative questions about women, power, and history.

Aston argues that Churchill's insertion of songs was "a way of exploring the possibilities of a feminist aesthetic" (Aston, 2001, p. 26), which explores the liminal in the interests of challenging the sign of Woman constructed by patriarchy system. Gillian Hanna, one of the founding members of Monstrous Regiment, who played the poor village girl, Alice, in the original production, explained that this style was to break down conventions of dramatic form, stating that they knew they had to have the music to "smash that regular and acceptable theatrical form" (Hanna, 1978, p. 9) since they didn't want to allow the audience to get off the hook by regarding it as a period piece, a piece of very interesting history. In doing so, they show their interests in exploring what she identified as a "counter-cultural, feminist style of performance" (Hanna, 1978, p. 9). In this sense, it is a more confrontational play, one that seeks to capture the audience with an argumentative mode of representation that removes any "neutral" space where the spectator may wish to stay.

Moreover, the songs' interruptions are not only Churchill's use of the dramaturgical devices of developing Brecht's idea of letting actors stand outside of their roles. It also conveys Churchill's postmodern acceptance of the role as a surface, to be possessed, used, and interrogated, but not to be accepted as an essential necessity. The insertion of the songs echoes Cixous' belief that "feminine writing is not merely a new style of writing; it is the very possibility of change, the space that can serve as a springboard for subversive thought, the precursory movement of a transformation of social and cultural standards" (Tong, 1998, p. 200). Cixous could easily be speaking of Churchill's plays when she comments that "[h]er language does not contain, it carries; it does not hold back, it makes possible" (Jacobus, 1999, p. 192). Anyway, contemporary songs, coupled with quotations from historical witchhunting manuals, contribute to the formation of a plurality of theatrical languages that are not easily appropriated by the current political discourse. It explores a counter-cultural feminist style of performance.

\section{Conclusion}

Vinegar Tom combines social commitment with theatrical experimentation. Rarely in modern British drama has the combination been so fruitful. Churchill has developed a duplicitous dramatic narration that emphasizes feminist theory and gender politics through episodic rhythmic structure, the ingenious role arrangement, and the interspersion of song to dramatic text. The narrative is disrupted, which stimulates the audience to question the binary representations prevalent in history as well as in contemporary life. Hence, its purpose is to impress the audience so as to bring about social change.

\section{Acknowledgements}

The essay is supported by National Social Science Foundation of China: "The Research on the narratology of family ethics in contemporary British Drama" (14BWW051).

\section{References}

Aston, E. (2001). Caryl Churchill. Plymouth: Northcote House Publishers Ltd.

Brecht, B. (1964). Brecht on theatre: the development of an aesthetic. Translated by John Willett. London: Methuen.

Churchill, C. (1985). Caryl Churchill Plays: One (Owners, Traps, Vinegar Tom, Light Shining in Buckinghamshire, Cloud Nine). London: Methuen Drama.

Cousin, G. (1989). Churchill, the Playwright. London: Methuen Drama.

Croft, S. (2001). She Also Wrote Plays-An International Guide to Women Playwrights from the 10th to the 21st Century. London: Faber and Faber Limited.

Demetz, P. (Ed.). (1962). Brecht: A Collection of Critical Essays. Englewood Cliffs, N.J.: Prentice-Hall Inc.

Hanna, G. (1978). Feminism and the theatre. Theatre Papers, 2nd series, No. 8. Devon: Darlington College.

Innes, C. (2002). Modern British Drama: The Twentieth Century. Cambridge: Cambridge University Press.

Itzen, C. (1980). Stages in the Revolution: Political Theatre in Britain Since 1968. London: Methuen Drama. 
Jacobus, L. A., \& Barreca, R. (1999). Hélène Cixous: Critical Impressions. London: Taylor \& Francis Group.

Kritzer, A. H. (1991). The Plays of Caryl Churchill: Theatre of Empowerment. London: The Macmillan Press Ltd. https://doi.org/10.1007/978-1-349-11460-3

Lanser, S. (1997). Towards a feminist narratology. In R. Warhol \& D. P. Herndl (Eds.), Feminisms: An anthology of literary theory and criticism (2nd ed., pp. 674-693). Brunswick, NJ: Rutgers University Press.

Randall, P. R. (Ed.). (1989). Caryl Churchill: A Casebook. New York: Garland Publishing Inc.

Seal, S. K., \& Das, D. (2015). Gender Politics and Patriarchy in Caryl Churchill's Vinegar Tom. International Journal of Humanities \& Social Science Studies, May, 145-149.

Tong, R. P. (1998). Feminist Thought. Boulder: Westview.

Zadeh, M. R. M., \& Ouliaeinia, H. (2013). Caryl Churchill's Vinegar Tom: Beyond Feminism. Journal of Language Teaching and Research, 4(2), 310-316. https://doi.org/10.4304/jltr.4.2.310-316

\section{Copyrights}

Copyright for this article is retained by the author, with first publication rights granted to the journal.

This is an open-access article distributed under the terms and conditions of the Creative Commons Attribution license (http://creativecommons.org/licenses/by/4.0/). 